\title{
У „ХОЛОДНИХ ПОТОКАХ НЕЗ ЯСОВАНОСТІ”. НА ПЕРЕТИНІ ХУДОЖНІХ СВІТІВ НОВЕЛ ХУЛІО КОРТАСАРА Й ВАСИЛЯ ГАБОРА
}

\author{
АННА ГОРНЯТКО-ШУМИЛОВИЧ \\ Щецінський університет, Щецін - Польща \\ W „CHŁODNYM NURCIE TAJEMNICY”. \\ NA PRZECIĘCIU ARTYSTYCZNYCH ŚWIATÓW NOWELISTYKI \\ JULIO CORTÁZARA I WASYLA GABORA
}

\author{
ANNA HORNIATKO-SZUMIŁOWICZ \\ Uniwersytet Szczeciński, Szczecin - Polska
}

\begin{abstract}
STRESZCZENIE. W artykule dokonana została analiza porównawcza małej prozy wybitnego przedstawiciela realizmu magicznego - Argentyńczyka Julio Cortázara oraz „magicznej nowelistyki” ukraińskiego prozaika Wasyla Gabora. Na przykładzie wybranych tekstów Cortázara i Gabora określono cechy wspólne, łączące poetykę utworów obu pisarzy, w tym tzw. „neofantastykę”, warunkującą obecność cech pozostałych, takich jak: próba wniknięcia pod powierzchnię rzeczywistości, najczęściej przy braku jakichkolwiek fantastycznych motywów, oniryczność, nastrój grozy, niepokoju i napięcia, wprowadzenie motywów pogoni/ucieczki, labiryntu/pułapki, jak również charakterystycznego pejzażu dla uwypuklenia głównego konfliktu utworu, zaskakujące puenty, egzystencjalny wymiar, niekiedy też polityczny podtekst tekstu i in. Cechy owe sprawiaja, iż zarówno nowelistyka Cortázara, jak i Gabora doskonale wpisuje się w nurt literatury poszukującej głębokiego, ukrytego dna rzeczywistości.
\end{abstract}

\section{IN "THE COOL WATERS OF MYSTERY” \\ ON THE VERGE OF THE ARTISTIC WORLDS OF SHORT STORIES BY JULIO CORTÁZAR AND VASIL GABOR}

\author{
ANNA HORNIATKO-SZUMIŁOWICZ \\ University of Szczecin, Szczecin - Poland
}

ABSTRACT. This article includes a comparative analysis of the small prose of an outstanding representative of magic realism - Argentina's Julio Cortázar and "magic short-stories" of the Ukrainian prose writer Vasil Gabor. Basing on the selected works by Cortázar and Gabor, the article embraces determination of common features connecting the poetics of the works by both writers, including so called "neo-fantasy", conditioning the presence of the remaining features, such as: the attempt to probe into the surface of the reality, usually with the lack of any fantastic themes, oneirism, atmosphere of fear, anxiety and tension, introduction of themes of chaselescape, labyrinth/trap, as well as characteristic landscape to highlight the main conflict of the work, surprising culminating points, existential dimension, sometimes also the political implication of the work, etc. These features make short-story writing of both Cortázar and Gabor perfectly fitting into the genre of the literature searching for the deep, hidden layer of reality. 
$\mathrm{M}$ ісячні „холодні потоки нез ясованості”, замість „сонячного проміння життєвого тепла" починають домінувати, на думку Івана Хланти та Ігоря Лазоришина ${ }^{1}$, у найновішій українській літературі (це стосується і Василя Габора). Висновки, що їх зробили для себе критики після прочитання реально-фантастичної збірки новел Книга екзотичних снів та реальних подій львівського прозаїка Василя Габора, навіюють згадки про твори „найновітнішого парадоксаліста” (І.А. Тертерян ${ }^{2}$ ), майстра урбаністичної новели латиноамериканського „магічного реалізму” Хуліо Кортасара. Враження від прочитаного співпадають, залишаючи дезорієнтованого читача з багатьма запитаннями і жодною відповіддю, зате створюючи грунт для пошуків паралелей.

Коли у 1999 році світ побачила вищезгадана збірка Габора, критики не щадили похвальних слів на адресу публікації та ії автора. Визнана „рідкісною у наші часи книгою новел”, яка „давно уже стала реритетом”, захоплювала авторським „неповторним досвідом, перепущеним через традицію класичної новели"4. Шукаючи українських та світових контекстів новелістики Габора, згадувалось про майстра української лаконічної новели Василя Стефаника ${ }^{5}$. Самому Габору неодноразово ставили запитання, хто найбільше вплинув на формування його художнього світогляду, і той неодмінно вказував на вітчизняних письменників. Окрім вищезгаданого Стефаника - іще на Ольгу Кобилянську, називаючи їх „найулюбленішими давніми друзями”, яким „треба довіряти”, , а серед світових - на японську та латиноамериканську літератури ${ }^{7}$. Притім здається, що латиноамериканська проза мала вирішальний вплив на Габора-новеліста, про що він сам неоднократно згадував:

Коли в 1980 року я повернувся з війська, мені потрапив до рук старий номер „Всесвіту” за 1976 рік, № 2, у якому була надрукована добірка латиноамериканської прози, і вона перевернула для мене весь світ ${ }^{8}$.

3-моміж майстрів латиноамериканської новели, твори яких тоді у сільській бібліотеці мав щастя пізнати Габор, були, між іншим, такі знаменитості, як

${ }^{1}$ I. Х л а н т а, I. Л а з о р и ш и н, Екзотичні сни та реальні подї у прозі Василя Габора, [в:] „Кур’єр Кривбасу” 2001, № 10, с. 215.

${ }^{2}$ Цит. за: Ю. П о к а л ь ч у к, Магічний світ Хуліо Kopmacapa, [в:] Х. К о р т а с а р, Таємна зброя. Новели, упоряд., перед. і перекл. з іспанської Ю. Покальчука, Київ 1983, с. 7.

${ }^{3}$ В. Г а б о р, Книга екзотичних снів та реальних подій, Львів 2003, с. 4.

${ }^{4}$ Н. С л о б о д я н, Класична новела Василя Габора, [в:] „Поступ” 1999, ч. 108, с. 8.

5 „Цей карпатський ландшафт, ці знайомі персонажі, що немов просвічуються із новел іншого Василя із початку століття”. Див.: там само.

${ }^{6}$ Див.: В. Ш н а й д е р, Василь Габор: „Живучи іншими, я $і$ сам зазнав позитивних змін...”, [електронний ресурс:] http://www.litgazeta.com.ua/node/271 (18.12.2009).

${ }^{7}$ Див.: В. Г а $б$ о р, Украйнська література є оритінальною й позбавленою будь-яких комплексів мартінальності й меншевартості, [в:] його ж, Від Джойса до Чубая. Есеї, літературні розвідки та інтерв юе, Львів 2010, с. 120.

${ }^{8}$ Там само. 
Габріель Гарсіа Маркес, Хорхе Луї Борхес, Алехо Карпентьєр, Маріо Варгас Льоса, Мігель Анхель Астуріас, Хуан Рульфо чи врешті Хуліо Кортасар.

I саме естетичний відблиск новелістичної творчості останнього можна простежити у творах Габора. Притім, попри факт, що художні світи аргентинського й українського письменників перетинаються, у них, звичайно, чимало відмінних рис.

Прикметно, шо аргентинець Хуліо Кортасар й українець Василь Габор існують у різних дискурсивних площинах. Життєвий та літературний шляхи Кортасара вже завершилися (письменник помер у 1984 р.), тоді як Габор у розпалі життєвої і творчої енергії (він - 1959 року народження), зокрема і як загальновідомий видавець.

Кортасар - дуже плідний творець ${ }^{9}$. Габор - автор лише двох збірок новел: Книга екзотичних снів та реальних подій з 1999 року, яка писалась двадцять років та Про що думає людина з 2012 року, яка писалась місяців два-три, зате iii ідеї виношувалися майже п`ятнадцять літ, та низки есеїв та літературних розвідок про княжі міста, закарпатську прозу та пресу початку XX століття. Він залишається вірний жанрові новели, який, до речі, не дається йому легко. Як сам зазначав, „Я новеліст, а за життя можна написати лише дві вартісні новели" ${ }^{\prime 10}$. Для письменника „зрадити новелу - це як зрадити дружину, найближчу людину у своєму житті”,"

Як Кортасар, так і Габор дотримуються принципу лаконічності новелістичного жанру. Аргентинський письменник вмістив цікаві роздуми про особливості жанру малої прози в теоретичній праці Про короткі оповідання і справи до них дотичні (1969). Згідно з ним, добре оповідання має бути лапідарним, твореним „3 годинником в руці”, коротким, очищеним із зайвих елементів ${ }^{12}$. Його відомі, найбільш лаконічні новели начислюють дві-три-чотири сторінки, у тому числі Продовженість парків (1963), Прошу нікого не звинувачувати (1963), Ріка (1963), Друзі (1963) та ін.. А у Габора, „задивленого” у неперевершеного майстра української лаконічної новели початку XX ст. Василя Стефаника, що писав „коротко, сильно і страшно”, проза іще лаконічніша, „напружена, мов стиснута пружина, і ємна, мов поезія" ${ }^{\prime 2}$.

${ }^{9}$ Окрім численних збірок новел (Бестіарій (Bestiario), 1951; Кінець гри (Final del juego), 1956; Таємна зброя (Las armas secretas), 1959; Все вогні - вогонь (Todos los fuegos el fuego), 1966; Життя хронопів і фамів (Historias de cronopios y de famas), 1962; Восьмигранник (Octaedro), 1974 та ін.) - він автор віршів, драматичної поеми в прозі Королі (Los Reyes), 1949, знаменитих повістей (Гонитва (El perseguidor), 1958) та романів (Icnum (El examen), 1945; Виграші (Los premios), 1960; Гра в класики (Rayиela), 1963; 62. Модель для збирання (62/modelo para armar), 1968; Книга для Мануеля (Libro de Manuel), 1978), врешті есеїв.

${ }^{10}$ В. Г а б о р, Право на приватність, [в:] його ж, Від Джойса до Чубая..., зазнач. джерело, с. 131

${ }^{11}$ Див.: А. С в е н т а х, Василь Габор: „Зрадити новелу - це як зрадити дружину”, [електронний ресурс:] http://www.wz.lviv.ua/life/120693 (23.10.2012).

${ }^{12}$ J. C o r t a z a r, Ostatnia runda, tłum. Z. Chądzyńska, Kraków 1979, c. 16.

${ }^{13}$ Н. С л о б о д я н, зазнач. джерело. 
Обидва автори здобули визнання критиків у зрілому віці, коли їм було за сорок. Зірка кортасарівської слави загорілась на зламі п'ятдесятих/шістдесятих років, коли письменник був вже автором книг, які літературознавці обійшли увагою. Габора доцінили у його сорокарічному віці, причому популярність прийшла після публікації першої і єдиної на протязі п`ятнадцяти років збірки новел Книга екзотичних снів та реальних подій (1999).

Кортасар, попри факт, що майже половину свого свідомого життя і творчості прожив далеко від батьківщини, в Свропі, для читачів залишився справжнім аргентинцем. Саме аргентинське коріння визначило суть кортасарівської творчості. Незважаючи на безперечний вплив Едгара Алана По, оповідання якого, до речі, Кортасар бравурно переклав, а також французьких творців - Лотреамона, Гійома Аполлінера і Альфреда Жаррі, „основним витоком його фантастики, - зазначав Юрій Покальчук, - є сама латиноамериканська дійсність, своєрідна атмосфера латиноамериканського міста, зокрема Буенос-Айреса" ${ }^{14}$. Габор - новеліст зі Львова, родом із Закарпаття. Як сам зізнається, його дві любові - це Вічне Місто Львів і Закарпаття: „У мене таке враження, що я маю дві батьківщини - Львів і Срібну Землю"15.

Обидва автори - прозаїки-урбаністи. У центрі малої прози Кортасара - Буенос-Айрес, у Габора - Львів. Причому, Кортасар - декларований урбаніст, його новели - свідчення спалаху латиноамериканської „міської” прози, яка, на думку Покальчука ${ }^{16}$, почала розгортатися в більш розвиненій економічно, промислово і культурно Аргентині значно раніше, ніж в інших латиноамериканських літературах, виявляючи додатково свій найпродуктивніший напрямок - фантастичний. Новели Габора здебільшого віддзеркалюють характерне для української літератури неоднозначне, чи скоріш вороже ставлення до міста, яке образно можна проілюструвати як алітераційний ряд - антиномія, апофеоз, адаптація, тобто антиномія місто-село, апофеоз села, адаптація міста. Тому-то, слушно зазначала Надія Слободян, що „цей автор до досвіду урбаністичного пробування додає ще й якийсь генетичний родовий досвід, що дозволяє вийти йому до трансцендентного не втікачем-заручником фатуму, а вічним мандрівником у просторі слова" 17 .

Незважаючи на факт, що Кортасара традиційно зараховують до письменників латиноамериканської літератури „магічного реалізму”, а Габора до творців української „магічної новели” 80-90рр. ХХ ст., обох авторів єднає сам характер фантастичного, визначеного окремими дослідниками як „неофантастика”

${ }^{14}$ Ю. П о к а л ь ч у к, Сучасна латиноамериканська проза, Київ 1978, с. 155.

${ }^{15}$ В. Г а б о р, Я потрапив у саму гущу життя..., [в:] Від Джойса до Чубая..., зазнач. джерело, с. 157.

${ }^{16}$ Ю. П о к а л ь ч у к, зазнач. джерело, с. 156.

${ }^{17}$ Н. С л о б о д я н, зазнач. джерело.

${ }^{18}$ Термін „неофантастика” (lo neofantástico) відносно поетики творів Хуліо Кортасара ввів Хайме Алазракі. Див. Т. Р i n d e 1, Zjawy, szaleństwo i śmierć. Fantastyka i realizm magiczny w literaturze hispanoamerykańskiej, Kraków 2004, s. 204. 
„нефантастична фантастика”, ${ }^{2}$, „чудова повсякденність ${ }^{20}$, , ,ншша реальність „21 тощо. I хоча тільки останній термін торкається безпосередньо поетики творів Габора, всі вони безперечно відповідають характеристиці новелістичної манери обох авторів. „Нефантастична фантастика”, що перетинає художні світи Кортасара й Габора, зумовлює наявність цілого ряду спільних стильових ознак творів аргентинського й українського новелістів, у тому числі розхитування стійкої повсякденності під впливом таємничих, ворожих сил, як правило, без використання фольклорних образів, балансування на межі сну і дійсності, нагнітання атмосфери страху й тривоги, введення мотивів погоні/втечі, лабірин$m y / n a c m к и$, а також своєрідного пейзажу для підкреслення основного психологічного конфлікту творів, орієнтація на несподівану розв 'язку, екзистенційне спрямування творів тощо.

Перш за все на увагу заслуговує сама природа фантастичного у творах обох письменників. Незважаючи на факт, що у художньому розвитку Кортасара дослідники виділяють два етапи, перший з них фантастичний (ранні збірки оповідань Бестіарій (1951) і Кінець гри (1956)), другий - з обмеженим введенням фантастичних мотивів (Таємна зброя (1959) та Все вогні - вогонь (1966), переважну частину знаменитих оповідань Кортасара становлять твори, в яких по суті не знайти чисто фантастичних елементів. Такі новели, як Загарбаний будинок (1951), Ріка (1956), Мамині листи (1959), Жовта квітка (1956), Таємна зброя (1959), Південна автострада (1966), Автобус (1951), Вдруге (1975), Скасовані двері (1956), Пообідня прогулянка (1956), Прошу нікого не звинувачувати (1956) та інші починаються звичайно і тільки у ході розгортання сюжету вводиться елемент учуднення реальності. Справедливо зазначав інший видатний латиноамериканський письменник „магічного реалізму”, друг Кортасара Маріо Варгас Льоса, що „в кортасарівськім світі звичайна дійсність, яка піддається діянню прихованих сил, що штовхають ії у напрямку незвичності, починає тріскати. Сили ці не виповнюють ії цілком, створюючи враження якоїсь застиглості у густій, концентрованій атмосфері, де дійсність і реальність співіснують, проте не змішуються одна 3 одною"22. Тому-то Льоса

19 Термін „нефантастична фантастика” ввів український дослідник латиноамериканської прози „магічного реалізму” Юрій Покальук. Див., наприклад,: Ю. П о к а л ь ч у к, зазнач. джерело, с. 148-149.

${ }^{20}$ Термін „чудова повсякденність”, запозичений від сюрреалістів, використав при хактеристиці поетики творів Кортасара Маріо Варгас Льоса. Див.: M.V. L 1 o s a, Trębacz z Deyá, przeł. K. Adamska, [w:] „Literatura na Świecie” 1995, nr 5/6, s. 192.

${ }^{21}$ Про „проникнення в „іншу реальність” писала Ніна Мельник відносно української магічної новелістики 80-90 pp. XX ст. Українська дослідниця підкреслювала вплив досвіду латиноамериканців, зокрема того ж Кортасара, на розвиток української „магічної новели”, у тому числі малої прози Габора. Див.: Н. М е л ь н и к, Проникнення в іншу реальність (українська магічна новела наприкінці ХХ ст.), [в:] „Слово і Час” 1998, № 11, с. 46-47.

${ }^{22}$ M.V. L 1 o s a, op. cit., s. 190. 
доходить висновку, що Кортасар - це одночасно письменник-реаліст і фантаст $^{23}$. Подібно ж у Книзі екзотичних снів та реальних подій Габора тільки невелика частина творів, стилізована під олітературнені фольклорні оповіді, виписана на фольклорному тлі (Хамойша-колесо, Переговори, Любаска), у двох-трьох творах простежується використання нечисленних мотивів фольклорної фантастики (У кнайпі пані Рузі, Голос пізнього ивіту), решта - по суті позбавлена будь-яких елементів традиційної фантастики. Невипадково сам Габор підкреслював: „[...] основою майже всіх моїх новел ставали реальні події, врешті, й людські відчуття та сни - для мене також реальність ${ }^{24}$. У Габоровому паралельному світі, в якому, за словами самого письменника, „надто багато чорної й жорсткої реальності” 25 , подібно як в кортасарівському, наявне розхитування стійкої повсякденності під впливом таємничих, як правило, ворожих сил, зародження незвичного у внутрішньому просторі героїв, суттєвими $€$ архітектоніка твору, зсув реальності.

Більшості творів обох письменників притаманна своєрідна оніричність, балансування на межі сну і дійсності, що неодноразово зазначали самі творці. Свого часу Кортасар згадував: „Багато моїх фантастичних оповідань виникли на оніричній основі” ${ }^{\prime 2}$. Подібно у Габора, який підкреслював, що „у книжці все перемішано. І важко зрозуміти, де реальність, а де сон"27. У кортасарівських оповіданнях дія відбувається на рівні складної взаємодії сну - яви. Деякі $з$ них, у тому числі Вночі обличчям до неба (1956), де травмованому мотоциклісту сниться, що є ацтеком-жертвою (в результаті, ацтек-жертва марить про мотоцикліста) чи Сеньйорита Кора (1966), де події розгортаються у лікарні між сонним маренням і притомністю хворого хлопця, безпосередньо використовують мотиви сну. В інших, наприклад Ріка (1956), де герой пропускає повз вуха погрози жінки втопитися у річці, оскільки спить біля неї, щоб накінець зрозуміти, що лежить поруч потопельниці, мотив сну не з`являється безпосередньо, але художня реальність побудована за принципом сонних кошмарів ${ }^{28}$. Подібно у Габора. Перша новела „Книги” Полювання у втраченому просторі, за авторським зізнанням, „справді навіяна сном”29. Майже в кожній наступній наявний мотив сну: „Далі все койлося, ніби уві сні ${ }^{\prime 30}$, - так

${ }^{23}$ Там само.

${ }^{24}$ В. Г а б о р, Деміургом є сама література, [в:] його ж, Від Джойса до Чубая..., зазнач. джерело, с. 110.

25 Там само, с. 114.

${ }^{26}$ Див.: Т. P i n d e 1, op. cit., s. 205.

${ }^{27}$ Див.: В. Г а б о р, Сон і реальність, [в:] Про що думає людина. Візії та невигадані історіï, Львів 2012, с. 110.

${ }^{28}$ Див.: Т. P i n d e 1, op. cit., s. 206-207.

${ }^{29}$ Див.: В. Г а б о р, Сон і реальність, [в:] Про що думає людина..,, зазнач. джерело, с. 110.

${ }_{30}$ В. Г а $б$ о р, Потрапити в сад, [в:] його ж, Книга екзотичних снів..., зазнач. джерело, с. 21. 
згадує оповідач трагічний фінал недозволеної любові з новели Потрапити в сад. У новелі Ніч, що ховає усі дороги героїня, що не усвідомлює власну смерть, придрімує біля грубки у хаті батьків приятельки (Христя ніби провалювалася в сон. I саме тоді, як була ніби в напівсні, їй показала своє обличчя смерть $\left.{ }^{\prime 31}\right)$. Прикметно, що оповідач нерідко з`ясовує для себе, що кошмарні дії відбулись лише уві сні, причому він, як правило, глибоко травмований.

Як у Кортасара, так і в Габора у ході розгортання дії наявне поступове нагнітання атмосфери жаху. Прикметно, у творах обох авторів відсутні карколомні події з безліччю кривавих подробиць і курйозів, тим паче кровожерних монстрів, що чигають за кожним кутом. Провідне враження від прочитаного - відчуття непокою, що розбурхує читацьку уяву, призводить реципієнта до психічного дискомфорту, примушує задуматись, шукати смислу. „Вказати не неназиваючи. Зорієнтувати, не розповівши. Збудити тривогу в серці слухача і передпочування крику з пітьми, нічим того ж таки слухача-читача зримо не жахаючи" З2, - ось як влучно назвав Володимир Кашка творче завдання, що його собі визначив Габор, і яке повністю може відноситися і до майстра парадоксальних сюжетів - Кортасара.

Прикметно, що дії як кортасарівських, так і Габорових творів драматизуються мотивами погоні/втечі, лабіринту/пастки. Мотив погоні/втечі чи не центральний, як в оповіданнях Кортасара: Загарбаний будинок (поява таємничих інтрузів примушує брата з сестрою покинути власний дім), Автобус (двоє пасажирів намагаються вирватись 3 лещат смерті, покидаючи автобус повний мерців); Бестіарій (мешканці дому уникають тигра, походжаючого по дому 3 метою заполювати їх), Менади, (маестро з оркестром тікає перед збожеволілою від захвату публікою), Вказівки для Джона Хоувелла (випадковий глядач, вплутаний у незрозумілу інтригу, примушений тікати перед переслідувачами), Прошу нікого не звинувачувати (мужчина заплутується у власний светер i, втікаючи перед уявним напасником, випадає з вікна висотного будинку), Пообідня прогулянка (хлопець намагається втекти перед розумово відсталим братом) та ін.), так і в новелах Габора (Полювання у втраченому просторі - втеча оповідача перед невідомим мисливцем, Ми приречені, кохана - втеча сім ї̈ перед таємничими переслідувачами), Свідок - втеча очевидця від незнаних кривдників). Із мотивом погоні/втечі чітко пов'язаний мотив лабірин$m y /$ пастки. Як кортасарівські, так і Габорові герої, примушені втікати від таємничих переслідувачів, відчувають, що потрапили у пастку, з якої немає виходу, і з якої усіма зусиллями намагаються вирватися. Так, наприклад, враження безвиході штовхає до дії загнаного у глухий кут мужчину, що нещасно заплутався у власний светер з оповідання Кортасара Прошу нікого не звинува-

${ }^{31}$ В. Г а б о р, Ніч, щзо ховає усі дороги, [в:] його ж, Книга екзотичних снів..., зазнач. джерело, с. 15.

${ }^{32}$ В. К а ш к а, Наздогнати черепаху. 3 приводу прози Василя Габора, [в:] „Дзвін” 2002, № 4, c. 152. 
чувати ${ }^{33}$. Подібно у новелі Габора Сходи вгору $і$ вниз, молодий мужчина Марко, який зайшов за справами до старої кам'яниці, скоро орієнтується, що попав у кляту пастку, з якої ніяк не може вибратись, оскільки круті сходи безконечні: „Невже люди, потрапивши на изі сходи, уже ніколи не вертаються у свої домівки, тут марно гинуть?" 34 .

Обидва письменники використовують елементи пейзажу для підкреслення основного психологічного конфлікту твору. Прикметно, що у Кортасара будуть це головним чином (хоча не завжди) нестерпна спекота, відчуття духоти, про що вряди-годи натякають герої („після обіду в розпал спеки”, Kiнець гри; „шкода, що жара”, Брами неба; „важко спати у спекотну, липку ніч, коли комарі безнастанно дзижчать”, Бестіарій; „того золотистого пополудня, сповненого цвіркунів і запаху зілля”, Ідол з Кіклад; „в час сієсти сонце гріло мабуть ще сильніше, ніж попереднього дня", Південна автострада тощо ${ }^{35}$ ). У творах Габора переважають дошкульний мороз („мороз пробирався до тіла”, Ніч, щзо ховає усі дороги), пронизливий холод (,холод пробирав до кісток”, Потрапити в сад), безнастанний дощ (,а той дощ - уже всім остобісів”, Телеграма), непроглядний туман („навколишні гори і село в долині тонули в густому тумані, і навіть за крок важко щось було побачити", Голос пізнього ивіту) тощо ${ }^{36}$. В обох випадках пейзаж (спекотний у Кортасара, і відповідно, холодний у Габора) має нагнітати атмосферу неспокою і тривоги, підсилювати відчуття екзистенційної нудьги героїв, відчуття життєвої безвиході. У Кортасара пейзаж більш скупий, сповнює допоміжню роль, іноді тільки увиразнюючи емоційний стан героїв, тоді як у Габора - це важлива складова поетики творів.

Як для Кортасара, так і для Габора характерною є орієнтація на несподіванку, що вражає сприйняття. Обидва автори не пропонують читачеві єдиного тлумачення своїх творів. Як інтерпретувати кортасарівських таємничих інтрузів, що поступово загарбають дім у Загарбаному будинку, білих кроликів, якими блюває жилець орендованої квартири з оповідання Лист до незнайомої в Парижі чи тигра-людожера з оповідання Бестіарій. Тим більше, що неймовірні ситуації не шокують героїв, що сприймають їх беззастережно. Справедливо зазначав Томаш Піндель ${ }^{37}$, що кортасарівські оповідання описують неймовірні історії, не даючи жодних інтерпретаційних ключів, через що

\footnotetext{
${ }^{33}$ Відкривас очі і бачить п`ять чорних нігтів, націлених прямо в очі, вібруючих у повітрі, перед атакою на нього, вдається йому опустити повіки і кинутись дозаду, [...], щоб десь втікати, щоби врешті кудись дійти, де немає руки, ні светра, де тільки пахуче повітря овіває і супроводить його, і пестить, і дванадцять поверхів.

Zob. J. C o r t á z a r, Proszę nikogo nie winić, [w:] tegoż, Opowiadania 1, przeł. Z. Chądzyńska i M. Jordan, Warszawa 2011, s. 359.

${ }^{34}$ В. Г а б о р, Сходи вгору і вниз, [в:] Книга екзотичних снів..., зазнач. джерело, с. 126.

${ }^{35}$ Див.: J. C o r t á z a r Opowiadania 1..., op. cit., s. 70, 178, 198, 399, 631.

${ }^{36}$ Див.: В. Г а б о р, Книга екзотичних снів..., зазнач. джерело, с. 13, 17, 78, 128.

${ }^{37}$ T. P i n d e 1, op. cit., s. 207.
} 
читач не спроможний визначити характер описуваних подій. Тому-то, на думку польського дослідника, всі спроби інтерпретації здаються безуспішними ${ }^{38}$. Подібно Габор неодноразово підкреслював, що „добра книга - це та, яка не дає відповіді, а ставить запитання, і іiї можна читати з будь-якої сторінки" "з9. Важливим у творі $є$ „багатовимірність, багатоплановість і неоднозначність

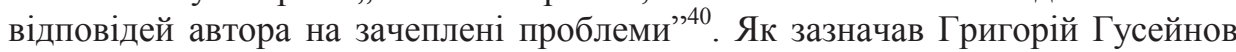
на полях Нотаток, про Форум видавців у Львові (2012), письменник „нікого не вчить, та й сам зайве не відкривається перед читачем, ніби дає тому змогу поступово й повільно дозрівати до розуміння написаного, ${ }^{\text {. }}$.

Незважаючи на факт, що для більшості творів обох авторів властиве універсальне загальнолюдське ідейне навантаження, деякі з них позначені виразним політичним забарвленням. Так, в оповіданні Кортасара Вдруге (1975) дівчина, викликана до невідомої установи, приходить на визначене місце, чекає у черзі, заповнює анкети. Відчуття невиразної тривоги охоплює іiі, коли з'ясовує, що хлопець, з яким вона розмовляла у приймальні і який прийшов до цієї установи вдруге, так і не вийшов звідти, оскільки іншого виходу з кімнати немає. Стривожений читач поволі усвідомлює, що коли дівчина прийде вдруге до цієї установи, зникне й вона. Новела може сприйматись як чергова парадоксальна історія, може теж інтепретуватись у політичному ключі. Виразною ідейно-тематичною срямованістю позначено також чимало творів Кортасара останнього періоду, у тому числі Кроки по слідах (1977), Апокаліпсис Солентінаме (1975), що невід`ємно пов язане з політичною заангажованістю письменника на схилі віку. Прикметно, що також його ранні новели, у тому числі Загарбаний будинок, дослідники пробують інтерпретувати у політичному ключі як алегоричний образ загроженої у період правління Перона аргентинської аристократії ${ }^{42}$. Подібно деякі новели Габора, принципово „незаангажованого у групівщину”, своїм ідейним навантаженням „схиляються” у бік політичних аналогій. Так, сюжет новели Ми приречені, кохана розгортається навколо мотиву втечі від невідомих переслідувачів. Заздалегідь заплановані дії, що їх реалізують утікачі (,Про все було домовлено заздалегідь, $i$ ми невимовно раділи, щз нарешті вирвемося з иього проклятого пекла"43), спрямовані на досягнення героями свободи („Та одне я знав твердо, хоч ми й приречені, ми

${ }^{38}$ Там само, с. 209.

${ }^{39}$ В. Г а б о р, Добра книга - не та, що дає відповіді, а та, щзо ставить запитання, [в:] його ж, Про що думає людина..., зазнач. джерело, с. 167.

${ }^{40}$ В. Г а б о р, Якби людина залишилася в раю, вона б ией рай зруйнувала, [в:] його ж, Про щзо думає людина.., зазнач. джерело, с. 116.

${ }^{41}$ Гр. Г у с е й н о в, „Юзю, мене пре від книжок...”, [електронний ресурс:] http://litukraina.kiev.ua/uziu-mene-pre-v-d-knizhok (01.10.2012).

${ }^{42}$ Див.: Т. P i n d e 1, op. cit., s. 206.

${ }^{43}$ В. Г а 6 о р, Ми приречені, кохана, [в:] його ж, Книга екзотичних снів..., зазнач. джерело, с. 32. 
все одно спробуємо звідсіля вирватися, скільки б разів не довелося ие роби$m u^{\text {"44 }}$ ). Також в оповіданні Свiдок молодий мужчина Юлій, ставши випадковим очевидцем брутального заштовхнення чоловіка-самітника у машину, примушений тікати перед таємничими переслідувачами: „Він розумів, що опинився у безвихідній ситуації $і$ що нема у нього жодної надії на рятунок" Промовисті деталі сюжету - постійне відчуття небезпеки, „чорна машина”, таємничі незнайомці у „чорних шкіряних плащах” з „блідими обличчями” й „червоними немигаючими очима” вказують на аналогію з неспокійними часами радянського режиму.

Переважна більшість творів обох письменників має проте чітке екзистенційне спрямування, в якому на першому плані знаходиться проблема нестерпної самотності людської одиниці, неможливість подолати життєвий вакуум тощо. Це може бути тому, що як в Кортасара, так і в Габора лейтмотивом проходить тема смерті. Так, кортасарівські герої здійснюють самогубство (Лист до незнайомої у Парижі, Ріка), стають жертвами вбивств (Друзі, Бестіарій, Таємна зброя, Продовженість парків, Ідол з Кіклад, Вказівки для Джона Хоувелла), вмирають після тривалої хвороби (Мамині листи, Жовта квітка, Брами неба, Сеньйорита Кора), врешті гинуть унаслідок нещасного випадку, як правило в парадоксальних обставинах (Прошу нікого не звинувачувати, Острів опівдні, Вночі обличчям до неба). Подібно у Габора, майже всі новели із Книги екзотичних снів та реальних подій торкаються теми смерті, у тому числі й тривожної звістки про чиюсь смерть (Телеграма), передчасної смерті близької людини (Потрапити в сад, Швони), страху перед смертю (У кнайпі пані Рузі), врешті неусвідомлення власної смерті, незгоди із нею (Поминки, Ніч, що ховає усі дороги). Тому-то недивно, що сам Габор зазначав: „Коли писав, мені здавалося, що я пишу про любов. Але, на превеликий жаль, любов невіддільна від смерті. Може, тому все справді закінчується сумно",

У розпалі буму латиноамериканської прози „магічного реалізму” 60-70 pp. $\mathrm{XX}$ ст., і зокрема у час іiі широкого резонансу в українському письменстві 70-80 pp. ХХ ст., не вщухали бурхливі дискусії про можливі паралелі між обома літературами - латиноамериканською і українською. Пригадується, як на одному із засідань „круглоло столу” з питань „Латиноамериканський роман і радянська багатонаціональна література", матеріали з якого надруковано згодом в унікальній публікації К диалогу. Латинская Америка: размышления о культуре континента (1986), Микола Ільницький з ентузіазмом першовідкривача згадував про свої враження від роману Лебедина зграя (1971) Василя Земляка, прочитаного безпосередньо після Ста років самотності (1967) Гарсіа Маркеса. Український критик „був вражений подібністю деяких

${ }^{44}$ Там само, с. 36.

${ }^{45}$ В. Г а б о р, Свідок, [в:] Книга екзотичних снів..,, зазнач. джерело, с. 119.

${ }^{46}$ Див.: В. Г а б о р, Сон і реальність, [в:] його ж, Про щзо думає людина.., зазнач. джерело, с. 110. 
дуже важливих стильових ознак в обох романах, зокрема концептуальною функцією елементів фольклорної фантастики" ${ }^{\text {,47 }}$, тип більше, що Земляк зарікався: роман Маркеса прочитав уже після написання Лебединої зграї. Аналогічна ситуація мала місце з Маркесом й Булгаковим. На цей раз Маркес божився, що не читав до написання свого шедевру Булгакового Майстра й Маргарити (1966).

Незважаючи на факт, що Габор не заперечував впливу на свою новелістичну творчість латиноамериканської прози „магічного реалізму”, мови немає про відверте епігонство. Парафразуючи слова Ільницького, одночасна лектура новел Габора і Кортасара „вражає подібністю деяких дуже важливих стильових ознак”, вводячи читача у „холодні потоки нез 'ясованості” „нефантастичної фантастики" і вкотре вже підтверджуючи реальність і неуникність паралелей між обома літературами, а то й окремими письменниками.

47 Див.: Латиноамериканский роман и советская многонациональная литература, [в:] К диалогу. Латинская Америка: размышления о культуре континента, под общей ред. и со вступ. статьей С.А. Микояна, Москва 1986, с. 362. 